\title{
THE EFFECT OF EGG SIZE ON YOLK UTILIZATION AND GROWTH OF RAINBOW TROUT ALEVINS (ONCORHYNCHUS MYKISS WALBAUM)
}

\author{
M. ÇALTA* \\ Faculty of Fisheries, University of Firat, 23119 Elazig, Turkey \\ (Received: May 10, 1999; accepted: February 5, 2000)
}

\begin{abstract}
Changes in body weight and yolk weight were studied in rainbow trout alevins derived from large eggs (diameter $>4 \mathrm{~mm}$ ) and small eggs (egg diameter $<4 \mathrm{~mm}$ ) from the same female.

Maximal body weight was reached later, and was higher, for alevins derived from large than from small eggs. The yolk was absorbed more quickly by the alevins of small eggs. Percentage of body water increased in alevins during fasting up to a limit of $91 \%$. Although the limit was the same for both groups of alevins, it was reached more quickly by alevins from small eggs. Relative water content of the yolk did not seem to be influenced by egg size. These results suggest that original egg size had both a quantitative and qualitative effect on the early development of alevins.
\end{abstract}

Keywords: Egg size - yolk utilization - growth - Oncorhynchus mykiss - rainbow trout - alevin

\section{INTRODUCTION}

Yolk is the major source of nutrients for salmonid before onsetting of exogenous feeding, although some dissolved nutrients may be taken up through the gills and skin [15]. The amount of yolk remaining at hatch depends upon original egg size and incubation conditions, particularly temperature [12] and oxygen supply [10].

Privol'nev et al. [24] found that original egg size had an effect only on the amount of yolk present at hatching, but not on the size of the alevins or on their future growth. On the other hand, other authors report that alevins from large eggs differ from small eggs in the following: higher hatching percentage [23], larger larval size at hatching [9] and larger larval size at the first feeding [17]. Bagenal [1] also reported better survival of larger alevins, either when released into the natural environment or fasted. These studies relate to comparisons of eggs from different females, so differences cannot be attributed to egg size per se.

The aim of this study was to examine the pattern of yolk utilization and growth of rainbow trout alevins derived from different-sized eggs of the same female.

\footnotetext{
*E-mail: mcalta@firat.edu.tr
} 


\section{MATERIALS AND METHODS}

This experiment was carried out at the laboratory of the Firat University, Fisheries Faculty. A brood female rainbow trout (3 years old, $62.2 \mathrm{~cm}$ in total length and 1320 $\mathrm{g}$ in weight) stripped of eggs and the eggs were fertilized with sperm from two males (3 years old, averaging $61.5 \pm 2.1$ in total length and $1227 \pm 53 \mathrm{~g}$ in weight). Adult fishes were obtained from Cip Fish Production and Research Centre of Firat University, Elazig, Turkey.

After fertilization, eggs were incubated in running, dechlorinated and filtered tap water in a fibreglass tank with stainless steel mesh hatching tray at a constant temperature of $7{ }^{\circ} \mathrm{C}$. At the eyed stage, the eggs were divided into two groups; diameter smaller than $4 \mathrm{~mm}$ and larger than $4 \mathrm{~mm}$. 500 eggs for each group were separately placed on incubators under the same conditions. The incubators were checked twice a day. Dead eggs were removed and recorded. At the hatching time, unhatched eggs were also removed and recorded for determination of hatching success.

After the hatching completed, 30 alevins were sampled from each group at 7 days interval between hatching and the free swim-up stage, then at 3 days intervals between the swim-up stage and the $50 \%$ mortality stage. The sampled fish were separately fixed in $10 \%$ formol until analysis.

At the end of experiment, fixed fish were dissected to separate the yolk from the body and then body and yolk were separately weighed in each sample in the wet state and then in the dry state after kept in an oven for $24 \mathrm{~h}$ at $104{ }^{\circ} \mathrm{C}$. At the same time, the water percentage of body and yolk of alevins were calculated by means of following formule.

$$
\% \text { of water contents }=\frac{\text { wet weight }- \text { dry weight }}{\text { wet weight }} \times 100
$$

Statistical analyses were performed by using Student's $t$-test after examination by Bartlett's test for the homogeneity of variance.

\section{RESULTS}

Hatching characteristics of egg groups are given in Table 1. The percentage of hatched eggs was higher in the large eggs-group (96\%) than in small eggs-group $(87 \%)$. The duration of incubation was slightly longer in small eggs compared with large eggs, but it was not significantly different $(\mathrm{P}>0.05)$.

Some growth characteristics of alevins during early development stage are given in Table 2. In both groups, dry body weight of alevins increased after hatching, reached a maximum, then decreased before complete yolk resorption. Alevins from small eggs reached their maximum weight earlier than alevins from large eggs. After the stage of maximal weight, alevins from both groups started to lose their body weight (Fig. 1). Dry yolk weight of alevins in both groups gradually decreased. The 
Table 1

Hatching characteristics of egg groups

\begin{tabular}{ccccc}
\hline $\begin{array}{c}\text { Egg diameter } \\
(\mathrm{mm})\end{array}$ & $\begin{array}{c}\text { No. of eyed } \\
\text { eggs in each group }\end{array}$ & $\begin{array}{c}\text { No. of } \\
\text { hatched eggs }\end{array}$ & $\begin{array}{c}\text { Duration of } \\
\text { incubation (days) }\end{array}$ & $\begin{array}{c}\text { Percent of } \\
\text { hatched eggs }\end{array}$ \\
\hline$>4$ & 500 & 480 & 44.5 & 96 \\
$<4$ & 500 & 435 & 45.0 & 87 \\
\hline
\end{tabular}

stage of full yolk resorption was reached earlier in small-egg alevins than in largeegg alevins (Fig. 1).

The percentage of body water of both groups of alevins increased from hatching to the $50 \%$ mortality stage (Fig. 2). At hatching time, no significant difference $(\mathrm{P}>0.05)$ on body water content was observed between two groups. However, at the same number of days after hatching, the small-egg alevins were more hydrated $(\mathrm{P}<0.001)$ than large-egg alevins (Fig. 2).

At hatching, the amounts of dry yolk weight stores were higher in large-egg animals than small-egg animals (Table 2). At this stage, the small-egg alevins had a yolk mean value of $11.7 \mathrm{mg}(72.2 \%$ of alevin weight) and large-egg alevins $20.7 \mathrm{mg}$ (76.7\% of alevin weight). Yolk water content (Fig. 3) increased significantly $(\mathrm{P}<0.001)$ between hatching and the swim-up stage at which all alevins still had yolk stores but did not differ between different egg group alevins $(\mathrm{P}>0.05)$.

Table 2

Some growth characteristics of alevins during early development stage

\begin{tabular}{|c|c|c|c|c|c|c|c|}
\hline \multirow{2}{*}{$\begin{array}{c}\text { Egg } \\
\text { diameter } \\
(\mathrm{mm})\end{array}$} & \multicolumn{2}{|c|}{$50 \%$ hatching stage } & \multicolumn{3}{|c|}{ Maximal body weight stage } & \multicolumn{2}{|c|}{$50 \%$ mortality stage } \\
\hline & $\begin{array}{l}\text { body dry } \\
\text { weight } \\
\text { (mg) }\end{array}$ & $\begin{array}{l}\text { yolk dry } \\
\text { weight } \\
(\mathrm{mg})\end{array}$ & $\begin{array}{l}\text { body dry } \\
\text { weight } \\
\text { (mg) }\end{array}$ & $\begin{array}{l}\text { yolk dry } \\
\text { weight } \\
(\mathrm{mg})\end{array}$ & $\begin{array}{l}\text { No. of days } \\
\text { after } \\
\text { fertilization }\end{array}$ & $\begin{array}{l}\text { body dry } \\
\text { weight } \\
(\mathrm{mg})\end{array}$ & $\begin{array}{l}\text { No. of days } \\
\text { after } \\
\text { fertilization }\end{array}$ \\
\hline$>4$ & $6.3 \pm 0.5$ & $20.7 \pm 1.2$ & $18.7 \pm 0.6$ & $1.53 \pm 0.7$ & 76 & $14.6 \pm 0.4$ & 85 \\
\hline$<4$ & $4.5 \pm 0.9$ & $11.7 \pm 1.3$ & $12.6 \pm 0.7$ & $1.33 \pm 0.3$ & 73 & $10.3 \pm 0.7$ & 82 \\
\hline
\end{tabular}

\section{DISCUSSION}

During the present study, sampled fish were fixed in $10 \%$ formol. This fixative brings about changes in body length and weight compared with that of live fish [11, 13]; nevertheless, it allows comparison between two groups because they were fixed under the same conditions. No significant effect of egg size on hatching time was observed. Similarly, intraspecific comparisons revealed no significant effects of fish egg size on hatching time $[3,16,19]$. 


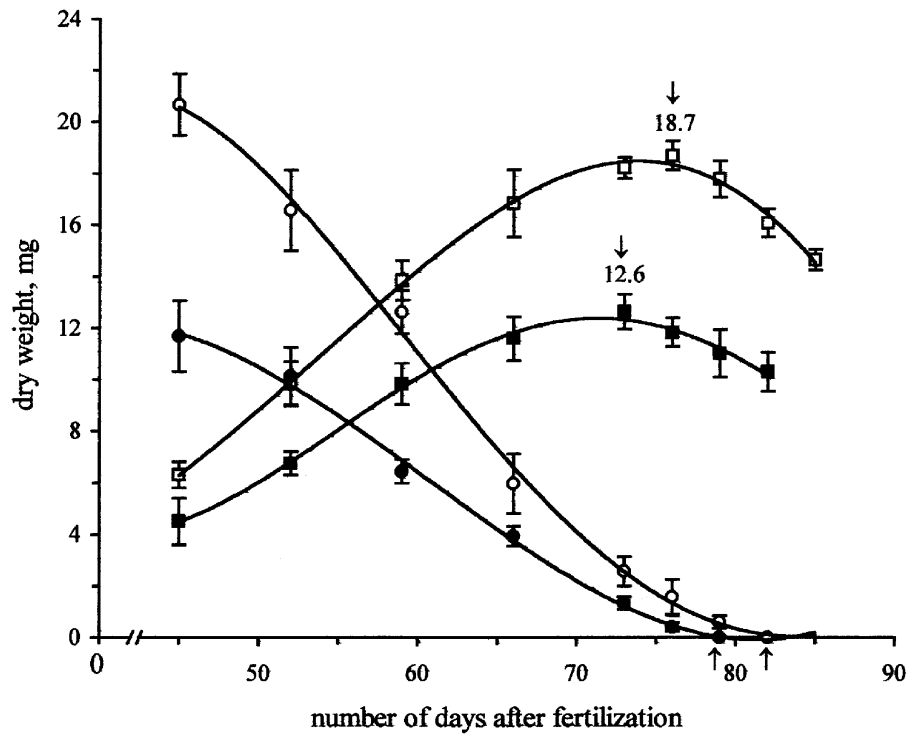

Fig. 1. Variation in body dry weight (derived from large eggs; $\square$ and small eggs; $\square$ ) and in yolk dry weight (derived from large eggs; $\circ$ and small eggs; $\bullet$ ) of alevins during the experiment $(n=10) . \downarrow$, maximal dry weight; $\uparrow$, full resorption of yolk

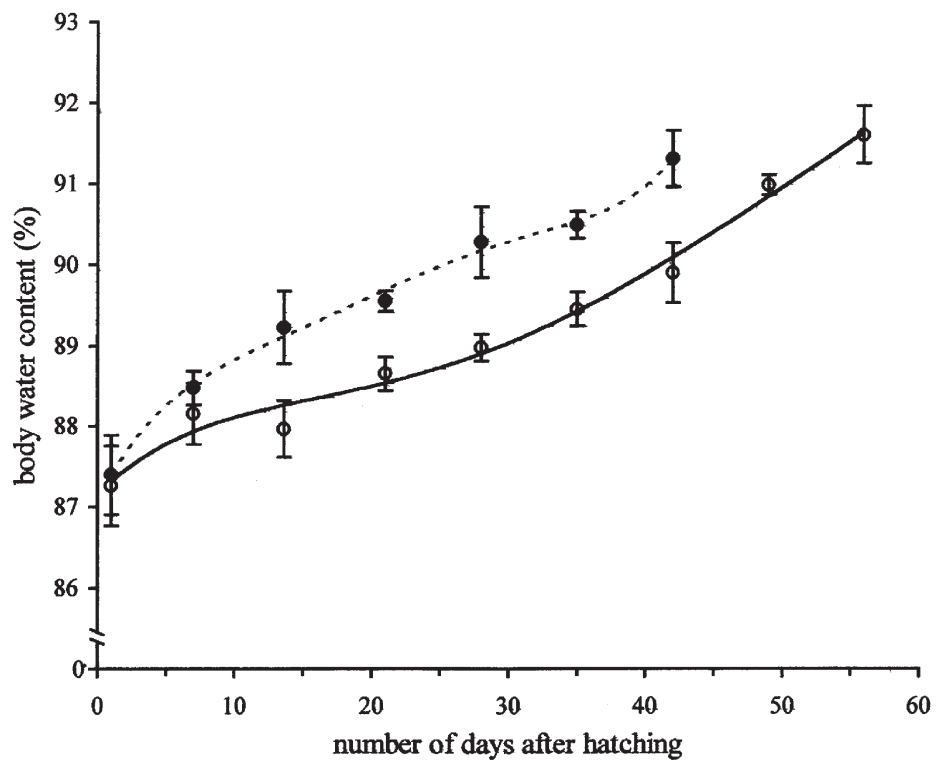

Fig. 2. Variation in body water content of alevins between $50 \%$ hatching and $50 \%$ mortality stage; small egg alevins (.......); large egg alevins (- 


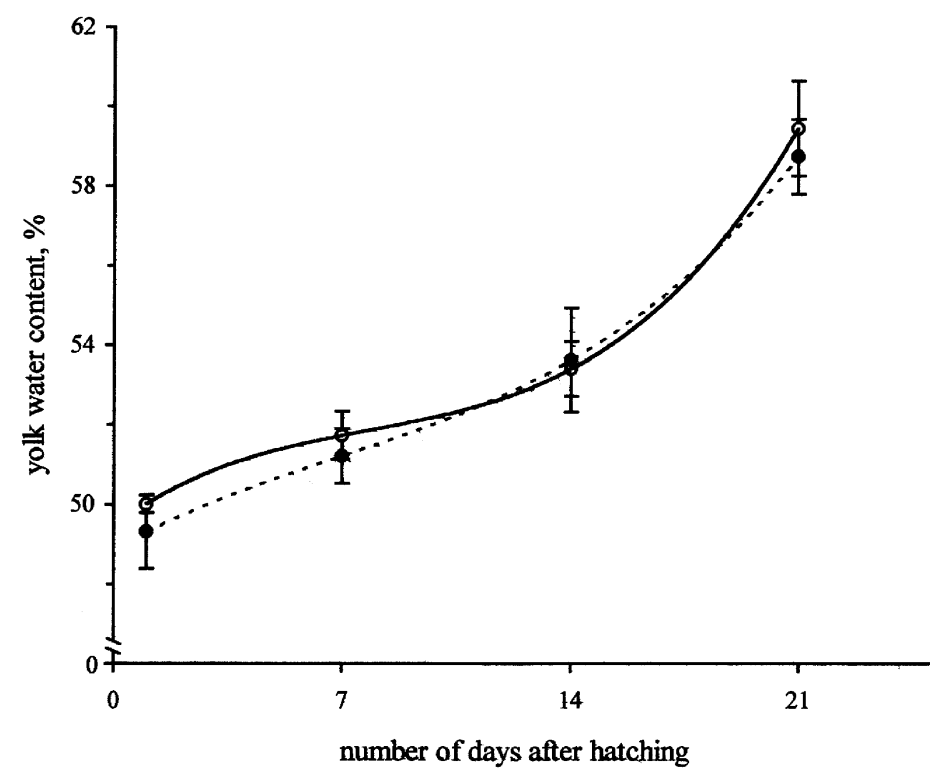

Fig. 3. Variation in yolk water content of alevins between $50 \%$ hatching stage and $50 \%$ mortality stage; small egg alevins (…...); large egg alevins $(-)$

The present study shows clearly that the dry body weight and the amount of yolk in large egg alevins was larger than in small egg alevins. These data contradict the conclusions of Privol'nev et al. [24] and Kazakov [17] in Atlantic salmon, but confirm those of Blaxter and Hempel [4] in herring, Beacham and Murray [2] in chub salmon, Hutching [14] in brook trout, Ojangures et al. [21] in brown trout, and Elliott and Hurley [8] in sea-trout. In the present study, body weight began to decrease earlier and yolk was exhausted more rapidly in small egg alevins, while the hatching date was not affected by original egg size. Many researches have reported more rapid resorption of yolk in small-egg alevins compared with large-egg alevins $[5,16,18$, 26]. Large eggs contribute to better survival for larvae through both a greater size of larvae and their longer survival prior to first feeding because of having higher amounts of yolk. Body size in larvae has been reported to be positively related with resistance to starvation $[19,20]$. Size differences in larvae but not female parent size were positively related to egg size $[2,6]$.

Peterson and Metcalfe [22] who studied Atlantic salmon, considered that body and yolk water content of alevins remained consant during yolk sac resorption. Our results indicate that these contents increase slightly but significantly with time. Similar findings to ours were reported by Ehrlich [7] in herring embryos.

Apart from egg size, yolk utilization and larval development are under the control of some environmental variables such as temperature, oxygen level, salinity and light. Yolk utilization and larval growth declined with decreasing temperature in 
Oncorhynchus mykiss [16] and in O. keta [2], and with decreasing oxygen level in Salmo salar [10]. In Scophthalmus maximus, high salinity of seawater (28\%) reduced the yolk absorption rate in comparison with brackish water $(17 \%)$, in which the larvae were below their point of neutral buoyancy and had to expend extra energy to keep from sinking [25]. Light delayed yolk utilization and larval growth in Salmo salar [27].

In conclusion, the present work suggests variations in body and yolk weight in rainbow trout alevins depending only on egg size, at least for the period between hatching and the end of yolk resorption. The results of the present work also show that there is a positive relationship between egg size and alevin size and between egg size and the amount of yolk available. So alevins derived from big eggs may have bigger size and better survival during early development stage.

\section{REFERENCES}

1. Bagenal, T. B. (1969) Relationship between egg size and fry survival in brown trout, Salmo trutta L. J. Fish Biol. 1, 349-353.

2. Beacham, T. D., Murray, C. B. (1985) Effect of female size, egg size, and water temperature on developmental biology of chum salmon (Oncorhynchus keta) from the Nitinat River, British Columbia. Can. J. Fish. Aquat. Sci. 42, 1755-1765.

3. Beacham, T. D., Withler, F. C., Morley, R. B. (1985) Effect of egg size on incubation time and alevin and fry size in chum salmon (Oncorhynchus keta) and coho salmon (Oncorhynchus kisutch). Can. J. Zool. 63, 847-850.

4. Blaxter, J. H. S., Hempel, G. (1963) The influence of egg size on herring larvae (Clupea harengus L.). J. Cons. Int. Explor. Mer. 28, 211-240.

5. Blaxter, J. H. S., Hempel, G. (1966) Utilization of yolk by herring larvae. J. Mar. Biol. Ass. U. K. 46, 219-234.

6. Baroudy, E., Elliott, J. M. (1994) Racial differences in eggs and juveniles of Windermere charr, Salvelinus alpinus. J. Fish Biol. 45, 407-415.

7. Ehrlich, K. F. (1974) Chemical changes during growth and starvation of herring larvae. In: Blaxter, J. H. S. (ed.) The early life history of fish. Springer-Verlag, Berlin, Heidelberg, New York, pp. 301-302.

8. Elliott, J. M., Hurley, M. A. (1998) Predicting fluctuations in the size of newly emerged sea-trout fry in a Lake District stream. J. Fish Biol. 53, 1120-1133.

9. Fowler, L. G. (1972) Growth and mortality of fingerling chinook salmon as affected by egg size. Progr. Fish Cult. 34, 215-225.

10. Hamor, H., Garside, E. T. (1977) Size relations and yolk utilization in embryos and alevins of Atlantic salmon, Salmo salar L., in various combinations of temperature and dissolved oxygen. Can J. Zool. $55,1892-1898$.

11. Hay, D. E. (1982) Fixation shrinkage of herring larvae: effects of salinity, formalin concentration and other factors. Can. J. Fish. Aquat. Sci. 39, 1138-1143.

12. Heming, T. A. (1982) Effects of temperature on utilization of yolk by chinook salmon (Oncorhynchus tshawytscha) eggs and alevins. Can. J. Fish. Aquat. Sci. 39, 184-190.

13. Heming, T. A., Preston, R. P. (1981) Differential effect of formalin preservation on yolk and tissue of young chinook salmon (Oncorhynchus tshawytscha Walbaum). Can. J. Zool. 59, 1608-1611.

14. Hutchings, J. A. (1991) Fitness consequences of variation in egg size and food abundance in brook trout, Salvelinus fontinalis. Evolution 45, 1162-1168.

15. Kamler, E. (1992) Early life history of fish: An energetics approach. Fish and Fisheries, Series 4. Chapman and Hall, London.

Acta Biologica Hungarica 52, 2001 
16. Kamler, E., Kato, T. (1983) Efficiencly of yolk utilization by Salmo gairdneri in relation to incubation temperature and egg size. Pol. Arch. Hydrobiol. 30, 271-306.

17. Kazakov, R. V. (1981) The effect of the size of Atlantic salmon, Salmo salar L., eggs on embryos and alevins. J. Fish Biol. 19, 353-360.

18. Knutsen, G. M., Tilseth, S. (1985) Growth, development, and feeding success of Atlantic cod larvae, Gadus Morhua, related to egg size. Trans. Am. Fish. Soc. 114, 507-511.

19. Marsh, E. (1986) Effects of egg size on offspring fitness and maternal fecundity in the orangethroat, Etheostoma spectabile (Pisces: Percidae). Copeia 1986, 18-30.

20. Miller, T. J., Crowder, L. B., Rice, J. A., Marchall, E. A. (1988) Larval size and recruitment mechanisms in fishes: toward a conceptual framework. Can. J. Fish. Aquat. Sci. 45, 1657-1670.

21. Ojangures, A. F., Reyes-Gavilan, F. G., Brana, F. (1996) Effects of egg size on offspring development nd fitness in brown trout, Salmo trutta L. Aquaculture 147, 9-20.

22. Peterson, R. H., Mercalfe, J. L. (1977) Changes in specific gravity of Atlantic salmon (Salmo salar) alevins. J. Fish. Res. Bd. Can. 34, 2388-2395.

23. Pitman, R. W. (1979) Effects of female age and egg size on growth and morality in rainbow trout. Progr. Fish Cult. 41, 202-204.

24. Privol'nev, T. I., Galkina, Z. I., Galkin, G. G. (1970) How the size of female salmon and of their eggs affects the progeny. In: Privol'nev, T. I. (ed.), Fish physiology in acclimatization and breeding. Israel Program for Sci. Transl., Jerusalem, TT 7050063.

25. Quantz, G. (1985) Use of endogenous energy sources by larval turbot, Scophthalmus maximus. Trans. Am. Fish. Soc. 114, 558-563.

26. Rombough, P. J. (1985) Initial egg weight, time to maximum alevin wet weight, and optimal ponding times for chinook salmon (Oncorhynchus tshawytscha). Can. J. Fish. Aquat. Sci. 42, 287-291.

27. Ryzhkov, L. P. (1976) Morpho-physiological peculiarites and transformation of matter and energy in early development of freshwater salmonid fishes. Kareliya, Petrozavodsk. (In Russian) 
